\title{
Neurorrhaphy Techniques: Comparative Stereological and Experimental Axonal Study
}

\author{
Técnicas de Neurorrafia: Estudio Experimental Estereológico Axonal Comparativo
}

\author{
Nagib Pezati Boer"; Fernando Batigalia**; Fausto Viterbo ${ }^{* * *}$; Humberto Regis de Paula Faleiros ${ }^{* * * *}$; Rogério Rodrigo Ra- \\ $\operatorname{mos}^{* * * * * *}$; Luciana Estevam Simonato******* \& Luis Fernando Ricci Boer
}

BOER; N. P.; BATIgAlia, F.; VITERBO, F.; FAleirOS, H. R. P.; RAMOS, R. R.; SiMONATO, L. E. \& BOER, L. F. R. Neurorrhaphy techniques: comparative stereological and experimental axonal study. Int. J. Morphol., 33(3):1002-1008, 2015.

SUMMARY: There is a great variety of injuries that affect peripheral nerves derived from acquired or congenital degenerative diseases affecting the central nervous system that cause loss of sensorimotor functions. The objective of this work was to perform an endto-side or side-to-side experimental axonal stereological study in order to compare volume density of axons, endouneuro and myelin sheath (and muscle mass) in peroneal and tibial nerves, with anastomosis contact from $0.25 \mathrm{~cm}$ to $0.50 \mathrm{~cm}$. After approval of the Ethics Committe, 20 male Wistar rats were divided into four groups of five rats each (G1= end-to-side neurorrhaphy; $\mathrm{G} 2=$ side-to-side neurorrhaphy of $0.25 \mathrm{~cm}$; G3= side-to-side neurorrhaphy of $0 \mathrm{~cm}$ and G4= Control of normality). After 180 days, fragments of peroneal and tibial nerves were collected for histological and stereological study. In comparative stereological experimental study between neurorraphies, the volume density of axons, myelin sheath of tibial and fibular nerves, as well as the post-surgical muscle mass, remains the same in end-to-side and side-to-side neurorraphies, regardless of contact area of anastomosis. It can be inferred, as surgical repair options, both end-to-side neurorrhaphy to recover and prevents atrophy of the endplate as side-to-side neurorraphy that is independent of the distance between the nerve stumps.

KEY WORDS: Neurorraphy; Reinnervation; Stereolog0y; Axon; Endoneurium; Myelin sheath.

\section{INTRODUCTION}

The trauma of peripheral nerves is relatively common and its complete transection leads to loss of motor and sensory functions (Colohan et al., 1996). Derived lesions or acquired degenerative diseases of the central nervous system also produce peripheral symptoms (Terzis et al., 1975). Therefore the use of neurorraphy to resume sensorimotor function advanced along with the evolution of the understanding of neurophysiology, anatomy and nerve regeneration, resulting in a more effective level of results obtained with the nerve repair techniques (Yüksel et al., 1999).

When a peripheral nerve is sectioned, Wallerian degeneration occurs in the distal stump, where the axon disintegrates by proteolytic action of enzymes present in the axoplasm. Macropages participate phagocytosing both the axon and Schwann cells, thus they prevent clogging in the next regeneration of the axon and synthesize the nerve growth factors (Stoll et al., 1989; Trumble, 2000).

Regeneration happens in dependence of physiological and surgical factors, and its success depends on the length of the space caused by the injury. Therefore, it is necessary, in the reconstruction of a nerve trunk, to reappoximate the nerve stumps by neurorrhaphy (Hakstian, 1973; Rosegay \& Edwards, 1980). The purpose of this microsurgical technique is the realignment of the nerve stumps with minimal surgical trauma.

\footnotetext{
PhD Professor, University Camilo Castelo Branco, UCCB and Foundation Education of Fernandópolis, FEF - Fernandópolis - São Paulo - Brazil.

** PhD Professor, São José do Rio Preto Medical School, FAMERP, São Paulo, Brazil.

*** $\quad$ PhD Professor, State University of São Paulo, Unesp- Botucatu, São Paulo, Brazil.

***** Master Professor, Camilo Castelo Branco University, Fernandópolis, São Paulo, Brazil.

****** Master Professor, University Camilo Castelo Branco and Education Foundation of Fernandópolis, Fernandópolis, São Paulo, Brazil.

******* Master Professor, Camilo Castelo Branco University, and Education Foundation of Fernandópolis, Fernandópolis, São Paulo, Brazil.

******** Medical Undergraduate, Anhembi Morumbi University, São Paulo, Brazil.
} 
Situations in which there is only a distal stump justify the attempt to get the reinnervation of it to the detriment of a healthy nerve that is not sectioned. These potential donors allowed vast options of anastomotic reconstruction, with many axon terminal buds crossing the reconstruction area toward the injured nerve. Neurotrophic factors, which the majority is derived from the target cells, are essential to the growth and reach the axoplasm intact by retrograde transport. Therefore, this work aims to conduct an esterological experimental axonal study of end-to-side and side-to-side post-neurorrhaphies to compare volume density of axons, endouneuro and myelin sheath (and muscle mass) in fibular and tibial nerves, with contact anastomosis between $0.25 \mathrm{~cm}$ and $0.50 \mathrm{~cm}$.

\section{MATERIAL AND METHOD}

We used 20 male Wistar rats, albinus variety, weighing between 300 and $350 \mathrm{~g}$, with an average age of 20 weeks from the laboratory animal center of São José do Rio Preto Medical School - FAMERP. The experiments complied with the Ethical Principles for Animal Experimentation established by the Brazilian College of Animal Experimentation (BCAE), approved by the Experimentation Ethics Committee (FAMERP - São José do Rio Preto Medical School) (Protocol 0554-2009).

The animals were divided into four groups, G1 (end-to-side neurorrhaphy), G2 (side-to-side neurorrhaphy with suture of $0.25 \mathrm{~cm}$ ), G3 (side-to-side neurorraphy with suture of $0.50 \mathrm{~cm}$ ) and G4 (denervated control). Each group consists of five rats.

Rats were anesthetized with xylazine and ketamine at a dose of $0.1 \mathrm{ml} / 100 \mathrm{~g}$, respectively, intramuscularly, and after the rats were ventrally positioned to trichotomy across the posterial part of the gluteal region, where the gluteal region of each group was operated, and maintained under observation for six months.

The neurorrhaphy assessment procedure was carried out by a fully randomized controlled study, where a longitudinal incision of approximately $4 \mathrm{~cm}$ was made to expose the sciatic nerve and its branches (fibular, tibial and sural). The fibular nerve of the four groups (G1, G2, G3 and G4) was sectioned to obtain two stumps, a proximal and distal one. In G1 (end-to-side neurorrhaphy), the proximal stump was medially bent and buried inside the adductor muscle. The distal stump was sutured to the tibial nerve without the removal of the epineurium, with its extremity sutured in an end-to-side manner (Fig. 1). In G2 (side-to-side neurorrhaphy with suture of $0.25 \mathrm{~cm}$ ) and in $\mathrm{G} 3$ (side-to-side neurorraphy with suture of $0.5 \mathrm{~cm}$ ), the proximal stump was medially bent and buried inside the gluteal muscle, and the distal stump was laterally bent with its extremity buried in the adductor muscle. These procedures were performed to keep the longest distance possible $(1 \mathrm{~cm})$ between the proximal and distal stump. Then, we performed side-to-side of $0.25 \mathrm{~cm}$ and $0.50 \mathrm{~cm}$ and without removal of the epineurium between the fibular and tibial nerve (Figs. 2 and 3). To measure the 0.25 and $0.5 \mathrm{~cm}$ suture,

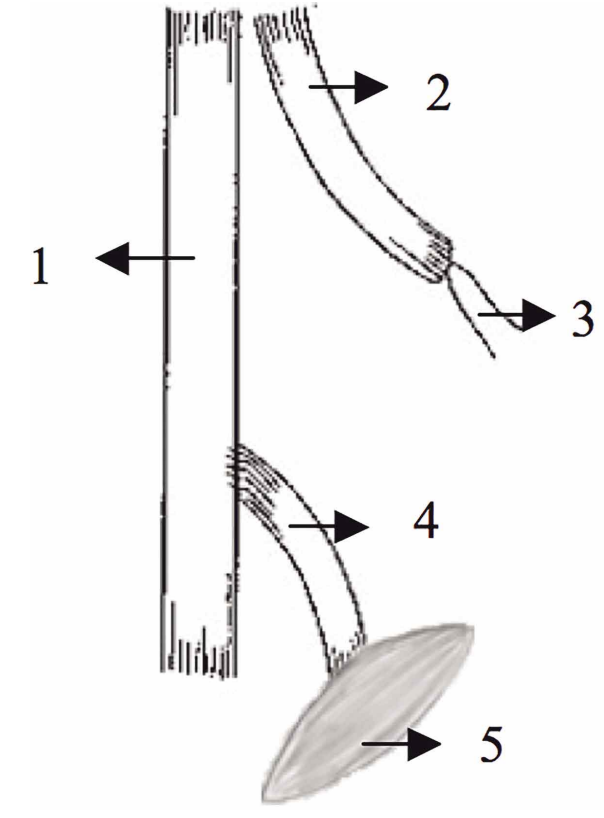

Fig. 1. G1: End-to-side neurorrhaphy. 1= Tibial nervel, $2=$ Proximal stump of fibular nerve, $3=$ Adductor muscle, $4=$ Distal stump of fibular nerve, $5=$ Cranial tibial nerve.

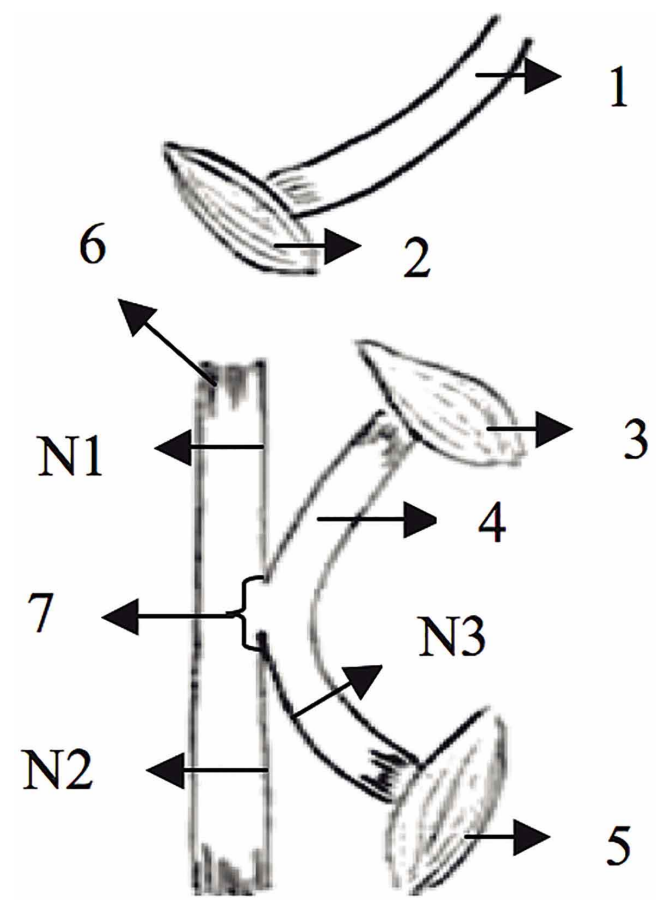

Fig. 2. G2: side-to-side neurorrhaphy with suture of $0.25 \mathrm{~cm}$. Where N1, N2 and N3 are cutting locations for manufacturing histological blades. $1=$ Proximal stump of fibular nerve, 2= Gluteus muscle, $3=$ Adductor muscle, 4= Distal stump of fibular nerve, $5=$ Cranial tibial muscle, $6=$ Tibial nerve, $7=$ Sideto-side neurorrhaphy site $(0.25 \mathrm{~cm})$. 
we used DBMCO GERMANY STAINIES caliper. In G4 (denervated control), the proximal stump was bent and sutured to the adductor muscle and the distal stump to the cranial tibial muscle (Fig. 4). This group was used as a denervation control group. All left members were used as a normal control group. The neurorrhaphy procedure was performed with the aid of $6 \mathrm{x}$ BIOART bi ocular lenses.

The rats were housed in appropriate cages at FAMERP laboratory animal center, separated by group and receiving the same care with commercial feed and ad libitum water, with controlled lighting and an average temperature of $24^{\circ} \mathrm{C}( \pm 0.5)$. After an interval of 6 months, the rats were sacrificed and the cranial tibial muscles and (tibial and fibular) nerves were collected for histological and stereological study.

For histological technique, the tibular and fibular nerves fragments were fixed in $10 \%$ formaldehyde and embedded in paraffin. They were then transversely cut $0,5 \mathrm{~mm}$ thick and stained with Masson Trichrome. The cranial tibial muscles were removed and weighed on a precision scale. The stereological parameters considered for the study of tibial and fibular nerves (axons, endoneuros and myelin sheath) was the volumetric density. For the compilation of stereological data, Image Pro Plus version 6.0 software was used.

We used the nonparametric Mann-Whitney test for statistical evaluation of quantitative data in order to verify the volume density of tibial and fibular nerves and muscle mass of cranial tibial muscles among the groups, adopting a 5\% significance level.

\section{RESULTS}

The percentages of incidents points over axon, endoneurium and myelin sheath of the tibial and fibular nerves from each group were analyzed, the results are presented in (Tables I and II), and the muscle mass of the cranial tibial muscle in Figure 5.

Statistical data were obtained for neurorrhaphy groups (G1: end-to-side neurorrhaphy, G2: side-to-side neurorraphy with suture of $0.25 \mathrm{~cm}$ and $\mathrm{G} 3$ : side-to-side neurorrhaphy with suture of $0.5 \mathrm{~cm}$ ), showed that there was significance between axons, endoneurium and myelin of tibial nerves $(p=0.0079)$, except the endoneurium from $\mathrm{G} 1$ and the myelin sheath from G2 and G3, with no significant statistical difference. The surgeries in G1, G2 and G3 of the fibular nerves (axons, endoneurium and myelin sheath) showed no statistical difference among the groups.

A comparison of mean volume density of the fibular nerve showed a significant reduction in the numbers of axons and sheaths of end-to-side neurorrhaphy (G1), side-to-side neurorrhaphy with suture of $0.25 \mathrm{~cm}(\mathrm{G} 2)$ and side-to-side neurorrhaphy with suture of $0.5 \mathrm{~cm}(\mathrm{G} 3)$ compared with the denervation control group (G4), with

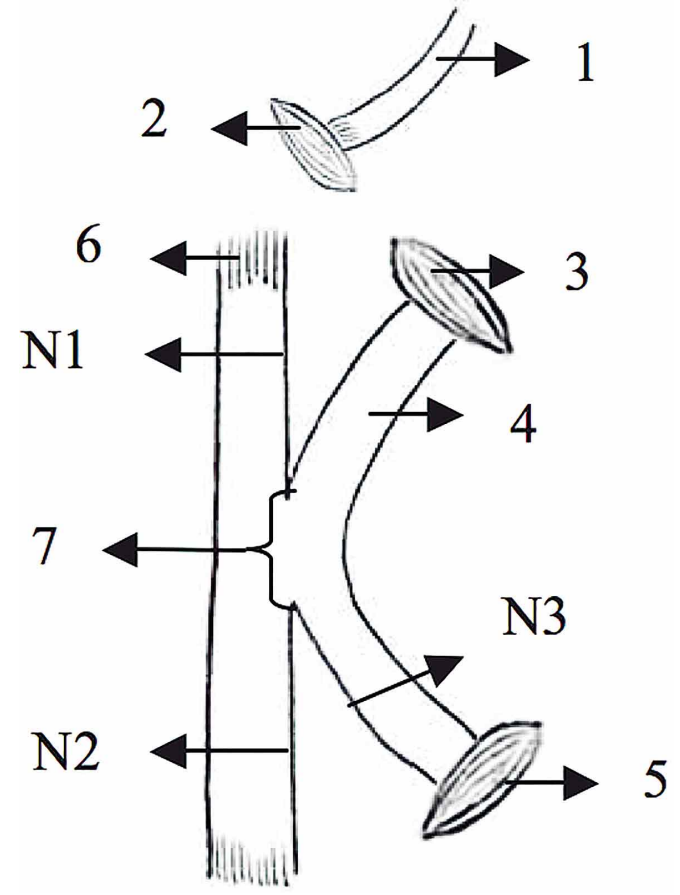

Fig. 3. G3: side-to-side neurorrhaphy with suture of $0.5 \mathrm{~cm}$. Where $\mathrm{N} 1, \mathrm{~N} 2$ and $\mathrm{N} 3$ are cutting locations for manufacturing histological blades. $1=$ Proximal stump of fibular nerve, $2=$ Gluteus muscle, $3=$ Adductor muscle, $4=$ Distal stump of fibular nerve, $5=$ Cranial tibial muscle, $6=$ Tibial nerve, $7=$ Side-toside neurorrhaphy site $(0.50 \mathrm{~cm})$.

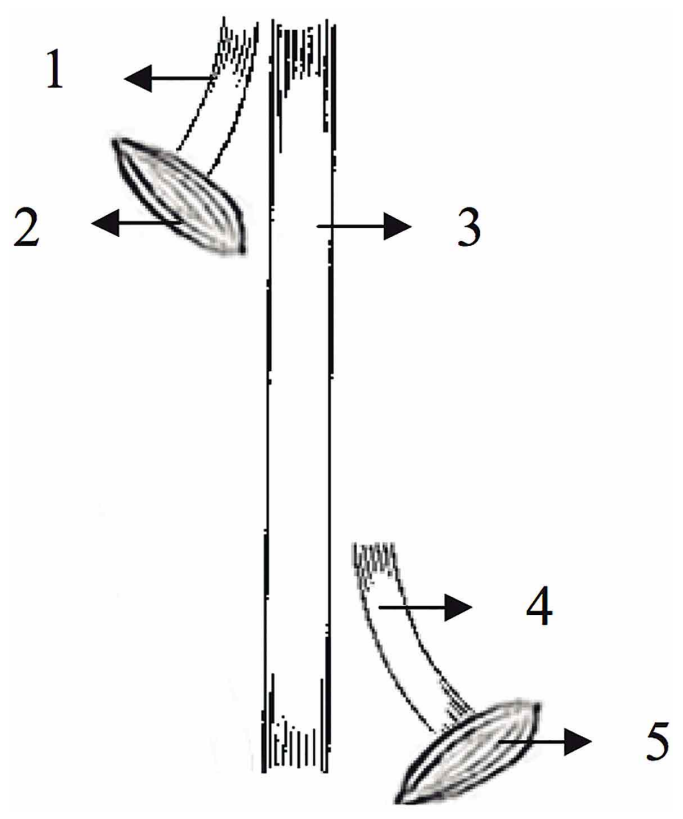

Fig. 4. G4: Denervation control group. 1= Proximal stump of fibular nerve, $2=$ Gluteus muscle, $3=$ Tibial nerve, $4=$ Distal stump of fibular nerve, $5=$ Cranial tibial muscle. 
Table I. Percentage of incident points over axon, endoneurium and myelin sheath of the tibial nerve.

\begin{tabular}{lcccc}
\hline & G1 & G2 & G3 & G4 \\
\hline Axons & $16 \%$ & $12 \%$ & $10 \%$ & $23 \%$ \\
Endoneurium & $37 \%$ & $54 \%$ & $54 \%$ & $34 \%$ \\
Myelin sheath & $42 \%$ & $26 \%$ & $28 \%$ & $28 \%$
\end{tabular}

G1= end-to-side neurorrhaphy; G2= side-to-side neurorrhaphy with suture of $0.25 \mathrm{~cm} ; \mathrm{G} 3=$ side-to-side neurorrhaphy with suture of $0.5 \mathrm{~cm}$ and $\mathrm{G} 4=$ denervated control group.

Table II. Percentage of incident points over axon, endoneurium and myelin sheath of the fibular nerve.

\begin{tabular}{lcccc}
\hline & G1 & G2 & G3 & G4 \\
\hline Axons & $12 \%$ & $12 \%$ & $9 \%$ & $14 \%$ \\
Endoneurium & $47 \%$ & $53 \%$ & $51 \%$ & $33 \%$ \\
Myelin sheath & $34 \%$ & $28 \%$ & $30 \%$ & $44 \%$ \\
\hline
\end{tabular}

G1= end-to-side neurorrhaphy; G2= side-to-side neurorrhaphy with suture of $0.25 \mathrm{~cm} ; \mathrm{G} 3=$ side-to-side neurorrhaphy with suture of $0.5 \mathrm{~cm}$ and $\mathrm{G} 4=$ denervated control group.

just side-to-side neurorraphy $0.50 \mathrm{~cm}$ from axon and side-to-side neurorraphy $0.25 \mathrm{~cm}$ from myelin sheath with a lower score, however, the mean volume density of the numbers of endoneurium did not show significant reductions (Fig. 6).

The comparison of average made in the tibial nerve showed a significant reduction of the volume density of the numbers of axons with end-to-side neurorrhaphy (G1), side-to-side neurorrhaphy with suture of $0.25 \mathrm{~cm}(\mathrm{G} 2)$ and side-to-side neurorrhaphy neurorraphy with suture of $0.5 \mathrm{~cm}(\mathrm{G} 3)$, when compared with the denervated control group (G4), with just sideto-side neurorraphy of $0.50 \mathrm{~cm}$ with a lower score, however, the mean volume density of the numbers of

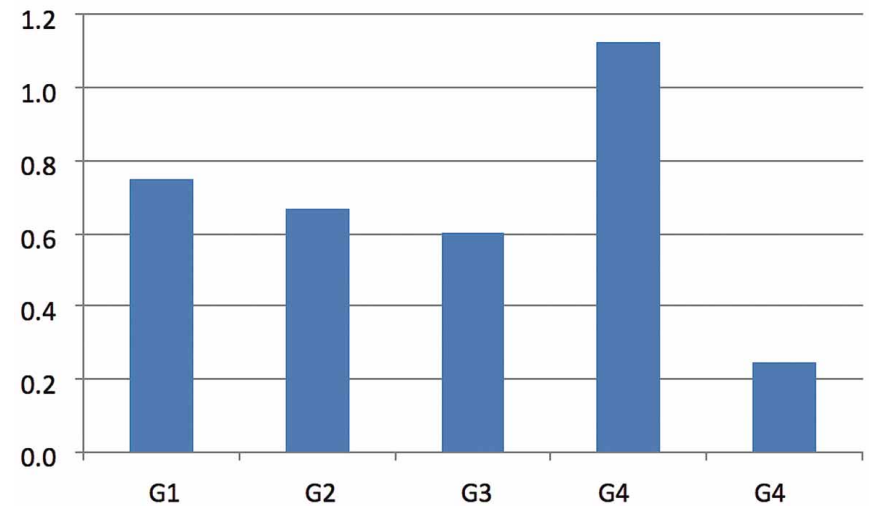

Fig. 5. Arithmetic mean of cranial tibial muscle in all groups.

endoneurium did not show significant reductions. Regarding the volume density of the myelin sheath, the end-to-side neurorrhaphy showed higher arithmetic mean in relation to the control group, while the side-to-side neurorrhaphy of 0.50 $\mathrm{cm}$ showed similarity to the control group. We only highlighted the side-to-side neurorraphy of $0.25 \mathrm{~cm}$ when compared with the control group (Fig. 7).

In the evaluation of muscle mass (Fig. 6) the control group (G4) was divided into G4N (normal control group) and G4D (denervation control group) for comparisons with other groups. Therefore, the end-to-side neurorrhaphy group (G1) when compared with the normal control group (G4N) showed significant statistical difference $(\mathrm{p}=0.2222)$. We could also note some differences when the G2 and G3 were compared with normal control group $(\mathrm{G} 4 \mathrm{~N})$ and denervation control group $(\mathrm{G} 4 \mathrm{D})$ with $(\mathrm{p}=0.0079)$, and there was a difference between G4N and G4D. Taking into consideration these distinctions, the values between G1 and G4N is the smallest one.

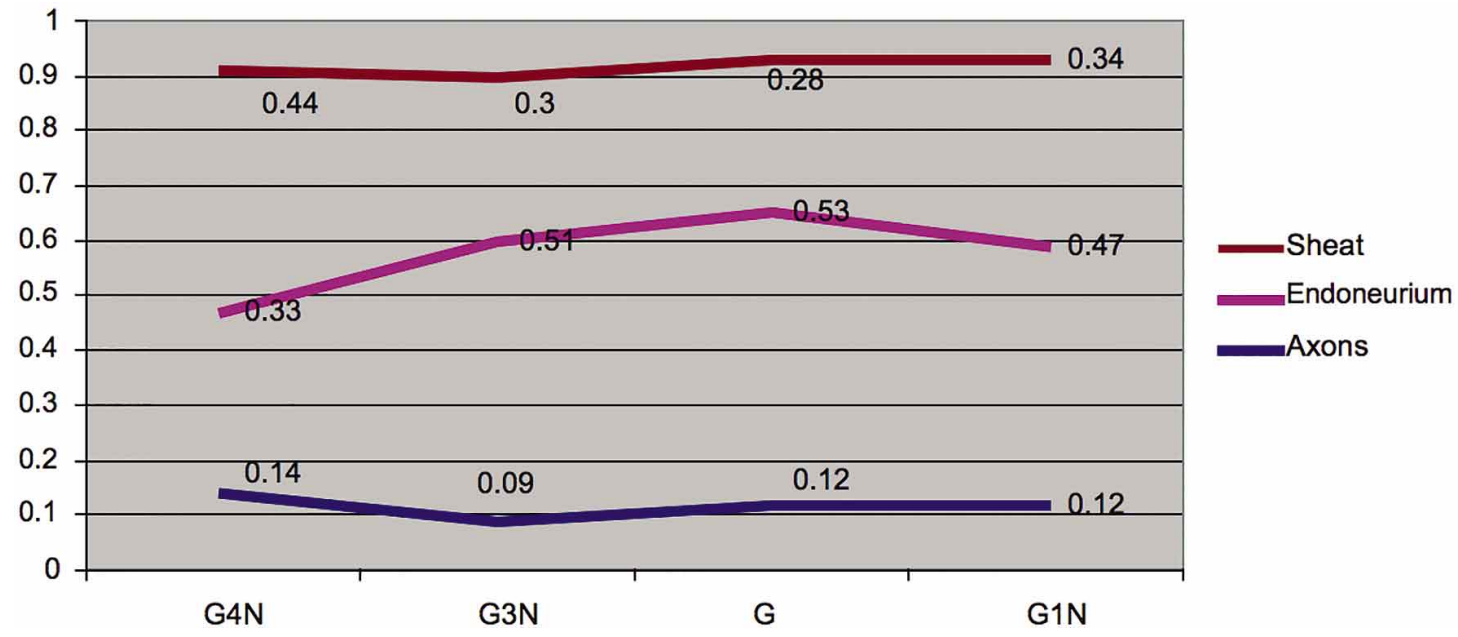

Fig. 6. Comparison of arithmetic mean of the volume density of axons, endoneurium and myelin sheath of the fibular nerve. 


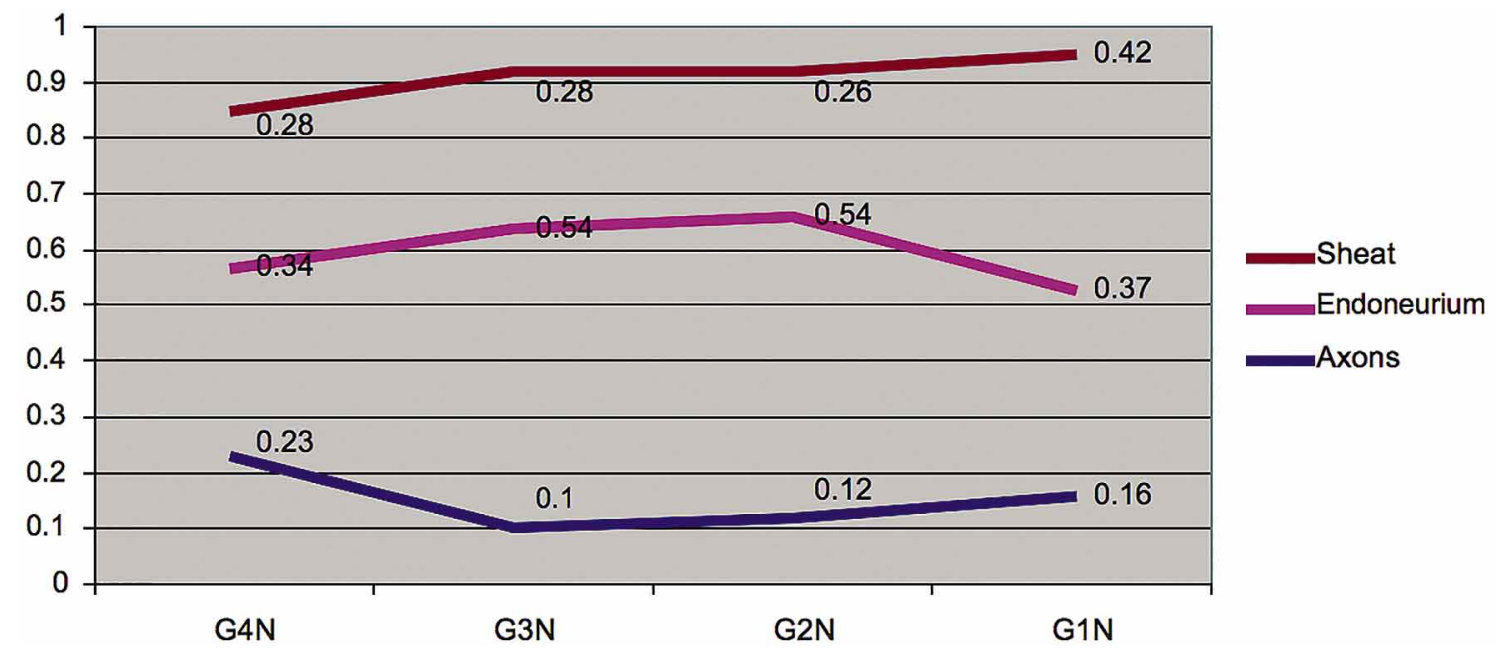

Fig. 7. Comparison of arithmetic mean of the volume density of axons, endoneurium and myelin sheath of the tibial nerve.

\section{DISCUSSION}

For nerve regeneration, multiple factors should be considered as appropriate environment to support axon growth and regeneration capacity of neurons after injury. In addition, the non-neural components are the most important in the regenerative process. They organize the injured area, direct the axonal growth and produce growth factors (Silva \& Camargo, 2010). The lack of nervous stimulation to the target organ leads to degenerative changes, which may be irreversible overtime. During this period, we can note the disappearance of motor endplates and as a consequence, muscle atrophy, and after that, fibrosis. Based on these facts, a reinnervation in a maximum of three months after the trauma is recommended (Fawcett \& Keynes, 1990; Mazzer et al., 2008).

The end-to-end neurorrhaphy is the technique of choice when there is proximity of the proximal and distal stumps, since their results are better for regeneration. However, there are situations where the access to one of the stumps is difficult and generally leads to some promising results due to the stress caused by the suture. Viterbo (1993) introduced the end-to-side neurorrhaphy without donor nerve injury or any damage to it, and reported that there was an axonal growth from the intact nerve toward the distal stump of the recipient nerve. The end-to-side neurorrhaphies with partial neurectomy were tested, however, the growth in the healthy nerve could cause fibrosis and stop the passage of nerve stimulation (Mennen, 2004).

The result showed that the neurorraphy performed in G1 (end-to-side neurorrhaphy), similar to that recommended by Viterbo (1993) obtained satisfactory results, confirming the findings of these researchers. However, Souza et al. (2011) performed end-to-side neurorrhaphy with and without the presence of epineural window, considering the minor differences and, moreover, concluded that these techniques do not promote sufficient remyelination. To circumvent the possible contamination of distal motor stump for growth of axonal sprouts originating from the proximal stump, the proximal stump extremity of the fibular nerve was inserted in adjacent muscle as recommended by Viterbo et al. (1993, 1994) and Kalliainen et al. (1999), thus it would be impossible to invalidate the results.

Side-to-side neurorraphies are independent of the distance between the stumps and have been recommended as viable alternatives and nerve grafts (Sanapanich et al., 2002), since they can promote both sensory as motor recovery (Xiong et al., 2003). In this technique, a large number of axonal sprouts may be able to cross the suture area and promote the role of neurotrophic factors to axonal growth with results similar to those of end-to-side neurorraphies. The absence of surgical section of the intact nerve minimizes risks related to dysfunction in the target tissue, neural atrophy and formation of undifferentiated neuroma, associated with local pain (Sato, 2005).

Researchers agree that the epineural suture is easy and simple to perform, requiring a smaller number of stitches, which reduces the trauma caused to the nervous tissue (Sawamura \& Abe, 1997; Dourado, 2002; Silva Neto, 2003). In fact, both the side-to-side suture with $0.25 \mathrm{~cm}$ as 0.50 $\mathrm{cm}$, did not show significant differences between them, 
distinguishing only on the size of the contact area with the healthy nerve. It is possible to infer that there is a certain independence of the size of the contact area and a dependence on the size of the suture.

The presence of regenerating axons was observed, although in smaller numbers and without performing the epineural window. Moreover, there was a presence of nerve fibers and Schwann cells with a degenerative appearance, which is believed to be remnants of Wallerian degeneration after trauma. This type of degeneration creates a favorable environment for axonal development from the presence of neurotrophic factors throughout the distal stump (Da Silva, 1995; Ide, 1996; Thanos et al., 1998). Fu \& Gordon (1997) suggested that these effects could also occur by paracrine or autocrine pathway in non-sensory cells of the distal stump and not by direct effects on axon regeneration, which was investigated in histological blades of distal sites of the receptor nerve coaptation. There were presences of secondary axonal sprouting to the injurysmall area, without any positive correlation between these injuries or even a greater number of myelinated fibers.

In comparative stereologic experimental study among neurorraphies, the volume density of axons, endoneurium and myelin sheath of tibial and fibular nervers are similar to post-surgical muscle mass, which remains the same in endto-side and side-to-side neurorraphies, regardless of anastomosis contact area.

We can infer that, both end-to-side neurorrhaphy that recover and prevents motor endplate atrophy as side-to-side neurorraphy that is independent of the distance between the nerve stumps are surgical repair options.

BOER; N. P.; BATIGALIA, F.; VITERBO, F.; FALEIROS, H. R. P.; RAMOS, R. R.; SIMONATO, L. E. \& BOER, L. F. R. Técnicas de neurorrafia: estudio experimental estereológico axonal comparativo.Int. J. Morphol., 33(3):1002-1008, 2015.

RESUMEN: Gran variedad de lesiones atingen a los nervios periféricos, derivadas de enfermedades adquiridas o degenerativas congénitas que afectan la parte central del sistema nervioso y que ocasionan pérdida de funciones sensoriomotoras. El objetivo de ese trabajo fue realizar un estudio experimental estereológico axonal post neurorrafias termino-lateral o latero-lateral para comparar densidad de volumen de axones, endoneuro y vaina de mielina (así como masa muscular) en nervios fibular y tibial, con unión de contacto entre $0,25 \mathrm{~cm}$ y $0,50 \mathrm{~cm}$. Tras la aprobación del comité de ética, fueran utilizados 20 ratones machos de la raza Wistar divididos en cuatro grupos de 5 ratones cada uno (G1= Neurorrafia término lateral; G2= Neurorrafia latero lateral de $0,25 \mathrm{~cm} ; \mathrm{G} 3=$ Neurorrafia latero lateral de $0,50 \mathrm{~cm}$ y G4= Control). Posteriormente, fragmentos de los nervios tibiales y fibulares fueron procesados para estudios histológicos y estereológicos. En el estudio experimental estereológico comparativo entre neurorrafias termino-lateral y latero-lateral, la densidad de volumen de axones, endoneuro y vaina de mielina de nervios tibial y fibular y también la masa muscular post quirúrgica se mantuvo equitativa, independientemente del área de unión de contacto. Podemos inferir como opciones de reparación quirúrgica, que el tratamiento de la neurorrafia termino-lateral y latero-lateral previnen la atrofia de placa motora, independiente de la distancia entre los muñones nerviosos.

PALABRAS CLAVE: Neurorrafia; Reinervación; Estereología; Axónes; Endoneuro; Vaina de mielina.

\section{REFERENCES}

Colohan, A. R.; Pitts, L. S. \& Rosegay, H. Injury to the peripheral nerves. In: Feliciano, D. V.; Moore, E. E. \& Mattox, K. L. (Eds.). Trauma. 3rd ed. Stamford, Appleton \& Lange, 1996.

Da Silva, C. F. Biologia celular e molecular da regeneração nervosa do sistema nervoso periférico. Atual. Neurociênc., 1(1):1-16, 1995.

Dourado, E. Reparación Microquirúrgica del nervio facial de conejo. Estudio comparativo de la sutura epineural y el sistema adhesivo de fibrina. Tesis de Doctorado en Odontología. Barcelona, Departamento de Ciencias Morfológicas y Odontoestomatología, Universidad de Barcelona, 2002.

Fawcett, J. W. \& Keynes, R. J. Peripheral nerve regeneration. Annu. Rev. Neurosci., 13:43-60, 1990.
Fu, S. Y. \& Gordon, T. The cellular and molecular basis of peripheral nerve regeneration. Mol. Neurobiol., 14(1-2):67-116, 1997.

Hakstian, R. W. Perineural neurorrhaphy. Orthop. Clin. North Am., 4(4):945-56, 1973.

Ide, C. Peripheral nerve regeneration. Neurosci. Res., 25(2):101-21, 1996.

Kalliainen, L. K.; Cederna, P. S. \& Kuzon, W. M. Jr. Mechanical function of muscle reinnervated by end-to-side neurorrhaphy. Plast. Reconstr. Surg., 103(7):1919-27, 1999.

Mazzer, P. Y.; Barbieri, C. H.; Mazzer, N. \& Fazan, V. P. Morphologic and morphometric evaluation of experimental acute crush injuries of the sciatic nerve of rats. J. Neurosci. Methods, 173(2):249-58, 2008. 
Mennen, U. End-to-side nerve suturing technique. J. Hand Surg. Br., 29(5):514, 2004.

Rosegay, H. \& Edwards, M. S. The language of neurorraphy. J. Neurosurg., 52(1):143-4, 1980.

Sanapanich, K.; Morrison, W. A. \& Messina, A. Physiologic and morphologic aspects of nerve regeneration after end-to-end or end-to-side coaptation in a rat model of brachial plexus injury. J. Hand Surg. Am., 27(1):133-42, 2002.

Sato, K. M. Comparação de neurorrafias término-terminais e término-laterais na reconstrução do nervo mediano: pesquisa experimental em ratos Wistar adultos. Monografia. Florianópolis, Universidade Federal de Santa Catarina, 2005.

Sawamura, Y. \& Abe, H. Hypoglossal-facial nerve side-to-end anastomosis for preservation of hypoglossal function: results of delayed treatment with a new technique. J. Neurosurg., 86(2):203-6, 1997.

Silva, C. K. \& Camargo, E. A. Mecanismos envolvidos na regeneração de lesões nervosas periféricas. Rev. Saude Pesqui., 3(1):93-8, 2010.

Silva Neto, J. C. Estudo clínico e histopatológico do uso de gangliosídeos na regeneração nervosa em ratos após axonotmesis. Dissertação de Mestre em Odontologia. Camaragibe, Faculdade de Odontologia de Pernambuco, Universidade de Pernambuco, 2003.

Souza, F. I.; Santos, G. B.; Silva, C. F.; Junior, R. M. \& Zumiotti, A. V. Avaliação histológica da neurorrafia término-lateral: estudo experimental em ratos. Acta. Ortop. Bras., 19(3):12931, 2011.

Stoll, G.; Griffin, J. W.; Li, C. Y. \& Trapp, B. D. Wallerian degeneration in the peripheral nervous system: participation of both Schwann cells and macrophages in myelin degradation. J. Neurocytol., 18(5):671-83, 1989.

Terzis, J.; Faibisoff, B. \& Williams, B. The nerve gap: suture under tension vs. graft. Plast. Reconstr. Surg., 56(2):16670, 1975 .

Thanos, P. K.; Okajima, S. \& Terzis, J. K. Ultrastructure and cellular biology of nerve regeneration. J. Reconstr. Microsurg., 14(6):423-36, 1998.

Trumble, T. E. Peripheral nerve injury: pathophysiology and repair. In: Feliciano, D. V.; Moore, E. E. \& Mattox, K. L. (Eds.). Trauma. 2nd ed. São Paulo, Guanabara Koogan, 2000 .

Viterbo, F. A new method for treatment of facial palsy: the crossface nerve transplantation with end-to-side neurorraphy. Rev. Soc. Bras. Cir. Plast. Estet. Reconstr., 8(1-2-3):29-38, 1993.
Viterbo, F.; Trindade, J. C.; Hoshino, K. \& Mazzoni Neto, A. End-to-side neurorrhaphy with removal of the epineurial sheath: an experimental study in rats. Plast. Reconstr. Surg., 94(7):1038-47, 1994.

Xiong, G.; Ling, L.; Nakamura, R. \& Sugiura, Y. Retrograde tracing and electrophysiological findings of collateral sprouting after end-to-side neurorrhaphy. Hand Surg., $8(2): 145-50,2003$.

Yüksel, F.; Karacaog `lu, E. \& Güler, M. M. Nerve regeneration through side-to-side neurorrhaphy sites in a rat model: a new concept in peripheral nerve surgery. Plast. Reconstr. Surg., 104(7):2092-9, 1999.

Correspondence to:

Phd Professor Nagib Pezati Boer

Avenue José Camargo de Arruda, 517

Fernandópolis

Zip Code: 15600-000

São Paulo

BRAZIL

Email: nagib.pezati@terra.com.br

Received: 03-11-2014

Accepted: 13-07-2015 